\title{
Alternative treatments diminish oviposition and viability of Leucoptera coffeella (Lepidoptera: Lyonetiidae) eggs and larvae on coffee plants
}

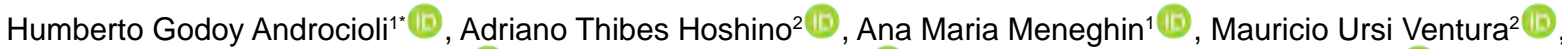 \\ Bruna Aparecida Guide ${ }^{1}(\mathbb{D})$, Fernando Teruhiko Hata ${ }^{(\mathbb{B}}$, Ayres de Oliveira Menezes Junior ${ }^{2}(\mathbb{B})$
}

\begin{abstract}
${ }^{1}$ Instituto de Desenvolvimento Rural do Paraná/IAPAR-EMATER, Departamento de Entomologia, Londrina, PR, Brasil
${ }^{2}$ Universidade Estadual de Londrina/UEL, Departamento de Ciências Agrárias, Londrina, PR, Brasil

Contact authors: handrocioli@idr.pr.gov.br; adriano.hoshino@uel.br; mventura@uel.br; anamariameneguim@gmail.com; bruna.guide@kroton.com.br; hata@uel.br; ayres@uel.br Received in June 22, 2021 and approved in November 11, 2021
\end{abstract}

\begin{abstract}
The effects of alternative treatments on the oviposition and viability of Leucoptera coffeella eggs and larvae were evaluated. Under controlled conditions, coffee sprouts cv. IAPAR-59, eight months old, were sprayed with brown propolis extract (1\%), pyroligneous extract with pepper and garlic (PEPG) (2\%), silicate clay ( $2 \%)$, kaolin (5\%), lime sulfur ( $2 \%)$, neem oil (1\%) and kaolin + neem oil $(5 \%+1 \%)$, distilled water and no treatment. In a first no-choice bioassay, coffee sprouts were sprayed before oviposition and kept in cages, where adult insects within three days after emergence were released. Adults remained in the cages for 24 hours. Eggs were then counted. 10 eggs per sprout were preserved to verify larval mortality. The number of eggs when treated with propolis extract, neem oil, kaolin + neem oil and PEPG decreased in the evaluations. Treatments with neem oil caused greater larval hindrance. Eggs laid on leaves were also sprayed with the treatments. Egg viability was reduced by treatments containing neem oil and lime sulfur. Neem oil treatments resulted in slim adult emergence; intermediate viability with lime sulfur and slight hindrance with silicate clay. Finally, treatments were also sprayed on leaves, hosting first or third instar larvae. Neem treatment caused high mortality for 1 st and $3^{\text {rd }}$ instar larvae, however, this effect was reduced when mixed with kaolin. Nonetheless, these negative effects disappeared when considering the adult survival ratio. Results indicated that propolis extract, PEPG and neem oil treatments are suitable for reducing egg deposition, neem oil considerably diminished larvae survival and adult emergence.
\end{abstract}

Key words: Coffea arabica L.; Organic coffee; Plant extracts; Coffee leaf miner.

\section{INTRODUCTION}

Brazil is the largest coffee (Coffea arabica L.) producer and exporter in the world. More than 49 million bags of coffee berry were harvested and 36 million bags were exported in 2019 (Companhia Nacional de Abastecimento - CONAB, 2020), generating revenues close to US\$ 5 bi (Conselho dos Exportadores de Café do Brasil- Cecafé, 2019). From 3 million hectare of cultivated coffee plants in Brazil (Conab, 2020), only 576 ha $(0.02 \%)$ is organically cultivated (Willer et al., 2021). In 2019, 709 thousand hectares (6.7\%) of the global coffee areas were certified as organic (Willer et al., 2021). This shows a great market potential for organic certified coffee in Brazil. Organic and other products certifications as Fairtrade, Rainforest Alliance and GlobalGAP may increase between $16 \%$ and $22 \%$ of farmers' incomes (Meemken, 2020). Thus, searching for sustainable production systems with reduced impacts on environment are crucial for farmers to be rewarded for providing ecosystem services.

The coffee leaf miner (CLM), Leucoptera coffeella Guérin-Mèneville \& Perrottet (Lepidoptera: Lyonetiidae) is one of the key pests that feed on coffee leaves. CLM seriously damages the production due to the defoliation (David-Rueda et al., 2016). The reduction in leaf surface area harms the photosynthesis process, carbohydrate content and, subsequently, berry production (Taiz et al., 2013).
CLM management is mostly with chemical control (Leite et al., 2020). The continuous use of insecticides, such as neonicotinoids, thiamethoxam and imidacloprid, without rotation of active ingredient or chemical group, can lead to a loss in insecticide efficiency, due to, selection of resistant insect populations and, furthermore, it may be economically unfeasible due to its high cost (Leite et al., 2020).

A promising alternative for this pest's management is the use of plant-based extracts and other phytoprotective mixtures with insecticide properties. Plants from the Meliaceae family are rich in allelochemical compounds and are an important source for insecticidal properties studies (Isman, 2020). The Azadirachta indica A. Juss. is the most studied plant and there are many reports of insecticidal activity against several species of insects (Benelli et al., 2016; Isman, 2020). Its most important active allelochemical, azadirachtin, causes inhibition of feeding and oviposition; induced hormonal system changes, which lead to disturbances in the development, deformations, infertility and mortality of insects (Benelli et al., 2016; Chaudhary et al., 2017).

There are many studies towards insect management alternatives for conventional chemical control. Lime sulfur, silicate rock powders and pyroligneous acid have negative effects such as repellency, inhibition of oviposition and feeding, and mortality of pest-arthropods (Alves et al., 2007; Azevedo 
et al., 2005; Eroglu; Emekci; Athanassiou, 2017; Gonçalves et al., 2015; Liška et al., 2017; Mmojieje; Hornung, 2015; Shah; Khan, 2014; Tuelher et al., 2014).

Thus, the objective of the study was to evaluate the effect of phyto protective mixtures, plant extracts and commercial treatments on the oviposition behavior, egg viability and survival of caterpillars of the coffee leaf miner, $L$. coffeella, in order to verify their potential for introduction into the integrated pest management of CLM.

\section{MATERIAL AND METHODS}

The experiments were carried out at the Entomology Laboratory of the Instituto de Desenvolvimento Rural do Paraná - Iapar - Emater, in Londrina, Paraná State. The experiments were performed in a room under controlled conditions $\left(25 \pm 1{ }^{\circ} \mathrm{C}, 70 \pm 10 \%\right.$ and a 14 :10, light: dark photoperiod).

\subsection{Insects}

Insects were collected from a coffee plantation, IAPAR 59 cV., located at Ibiporã county, Paraná State, in March and April of 2010. Leaves hosting L. coffeella larvae were placed in containers ( $50 \mathrm{~L}$ capacity) and taken to the laboratory. The leaves were inspected once a day and those containing pupae were transferred to cages ( $82 \times 60 \times 41 \mathrm{~cm}$ ), sealed with voile fabric. $12 \mathrm{~h}$ after emergence, adults were transferred to other cages similar to the previous ones and fed with a $10 \%$ aqueous solution of honey soaked in cotton. A stock population was maintained.

\subsection{Plants, spraying and treatments}

Tubes (volume of $120 \mathrm{~cm}^{3}$ ) containing coffee IAPAR $59 \mathrm{cv}$. sprouts, aged eight months, with more than four pairs of expanded leaves, were used in the experiments. Adaxial surfaces from coffee sprouts were sprayed with an airbrush (YANMAR SW 776), regulated at 2 BAR pressure. The sprouts were kept in cages $(80 \times 60 \times 60 \mathrm{~cm})$, sealed with voile fabric, under controlled conditions $\left(25 \pm 1{ }^{\circ} \mathrm{C}, 70 \pm 10 \%\right.$ and a 14-hour photoperiod).

Ethanolic extract of propolis at $15 \%\left(\mathrm{w} \mathrm{v}^{-1}\right)$ was prepared using dark brown propolis, in a moldable state, with about $60 \%$ impurities, obtained through the scraps from boxes of Apis mellifera mellifera. For its preparation, $300 \mathrm{~g}$ of propolis was diluted in $2 \mathrm{~L}$ of hydrated ethyl alcohol (92.8 INPM, Instituto Nacional de Pesos e Medidas). The mixture was stirred every 12 hours and, after 48 hours of preparation, the extract was filtered and stored.

To prepare the pyroligneous acid with pepper and garlic (PEPG), $300 \mathrm{~g}$ of chili pepper fruits (Capsicum frutescens L.) and $100 \mathrm{~g}$ of garlic (Allium sativum L.), were crushed and diluted in two liters of pyroligneous acid. After triturating in a blender for one minute, the extract was placed in a container and kept in the absence of light for 45 days. After this period, the solution was filtered and stored.

The silicate clay was obtained from the commercial product Rocksil ${ }^{\circledR}$, which contains the elements $\mathrm{Al}_{2} \mathrm{O}_{3}, \mathrm{SiO}_{2}$, $\mathrm{S}, \mathrm{CaO}, \mathrm{TiO}_{2}, \mathrm{MgO}, \mathrm{Fe}_{2} \mathrm{O}_{3}$ and $\mathrm{P}_{2} \mathrm{O}_{5}$, in the proportions of 20.56\%, 17.43\%, 9.82\%, 1.31\%, 0.34\%, 0.18\%, 0.16\% and $0.10 \%$, respectively. Kaolin $\left(\mathrm{Al}_{2} \mathrm{Si}_{2} \mathrm{O}_{5}(\mathrm{OH})_{4}\right)$ (Protesyl ${ }^{\circledR}$ ), contained $\mathrm{SiO}_{2} ; \mathrm{Al}_{2} \mathrm{O}_{3}$ and $\mathrm{H}_{2} \mathrm{O}$ in the proportions of $46.6 \%$, $39.5 \%$ and $13.9 \%$, respectively.

The neem seed oil contained $10 \mathrm{~g}$ azadirachtin $^{-1}$ $\left(\right.$ NeemAzal $^{\mathrm{TM}} \mathrm{T} / \mathrm{S}$ ) and the lime sulfur embodied a density of $32^{\circ}$ Baumé, comprising of ventilated sulfur, virgin lime and water, prepared according to Penteado (2000).

Two control treatments were used, distilled water and absent of treatments. The treatments and respective doses are shown in Table 1.

Table 1: Treatments and doses sprayed on coffee IAPAR 59 cV. sprouts for assessments of Leucoptera coffeella oviposition preference and larval mortality.

\begin{tabular}{cc}
\hline Treatments & Dose in water $(100 \mathrm{~mL})$ \\
\hline Ethanolic extract of propolis & $1 \mathrm{~mL}$ \\
Pyroligneous acid + pepper + garlic & $2 \mathrm{~mL}$ \\
Silicate clay & $2 \mathrm{~g}$ \\
Kaolin & $5 \mathrm{~g}$ \\
Neem seed oil & $1 \mathrm{~mL}$ \\
Lime sulfur & $2 \mathrm{~mL}$ \\
Kaolin + Neem seed oil & $5 \mathrm{~g}+1 \mathrm{~mL}$ \\
Control (Distilled water) & $100 \mathrm{~mL}$ \\
Control (Without spraying) & - \\
\hline
\end{tabular}

\subsection{No-choice oviposition test and mortality of Leucoptera coffeella larvae and pupae}

Distilled water, neem oil and kaolin + neem oil were sprayed just once, while propolis treatments; PEPG; silicate clay; kaolin and lime sulfur were sprayed weekly, with three repetitions, hoping to induce resistance mechanisms. For each treatment, 18 coffee sprouts were used (with about 6 pairs of fully expanded leaves), which were stored in rectangular cages, with the following dimensions, $80 \mathrm{x}$ $60 \times 60 \mathrm{~cm}$ (length, width and height, respectively). Each treatment had its own cage and each sprout was considered a repetition. The interval between the last spraying and the release of CLM adults for oviposition was four hours, releasing 200 moths, with three days after emergence, into each cage, where they remained for 24 hours. After that, the number of eggs on the leaves was counted using a stereomicroscope (Figure 1). 
After the eggs were counted, only 10 eggs per coffee sprout were sustained. Non-viable and excess eggs were discarded. The non-viable eggs differed because of their translucency and UV light ( 365 to $375 \mathrm{~nm}$ ) reflection, allowing their detection and removal with the help of a stereomicroscope. Each sprout was maintained in polyethylene bags $(20 \mathrm{x} 10 \mathrm{~cm})$, with more than 100 perforations, made with an entomological pin $\left(\mathrm{n}^{\circ} 1\right)$, granting gas exchange and avoiding water vapor congestion. Three days later, daily evaluations on the sprouts were overseen until every adult emerged, recording the number of lesions (mines) on the leaves, number of pupae and the number of adults that emerged (Figure 2). Eighteen replicates (one coffee sprout) per treatment were used.

\subsection{Viability of eggs}

Adults (620 total) with three days after emergence were released into cages $(80 \times 60 \times 60 \mathrm{~cm})$, each containing coffee sprouts, totaling 80 sprouts. After 16 hours, sprouts were removed from the cages and the eggs were inspected. Just five eggs per leaf were kept. Non-viable and excess eggs were discarded, with the help of a UV light (365 to $375 \mathrm{~nm}$ ), as mentioned before.

Plants were sprayed three days after oviposition and, 12 hours later, the coffee sprouts were conditioned in polyethylene bags, as previously described. Five replicates per treatment were used. Assessment onset was three days after spraying, using the same procedures from the previous bioassay.

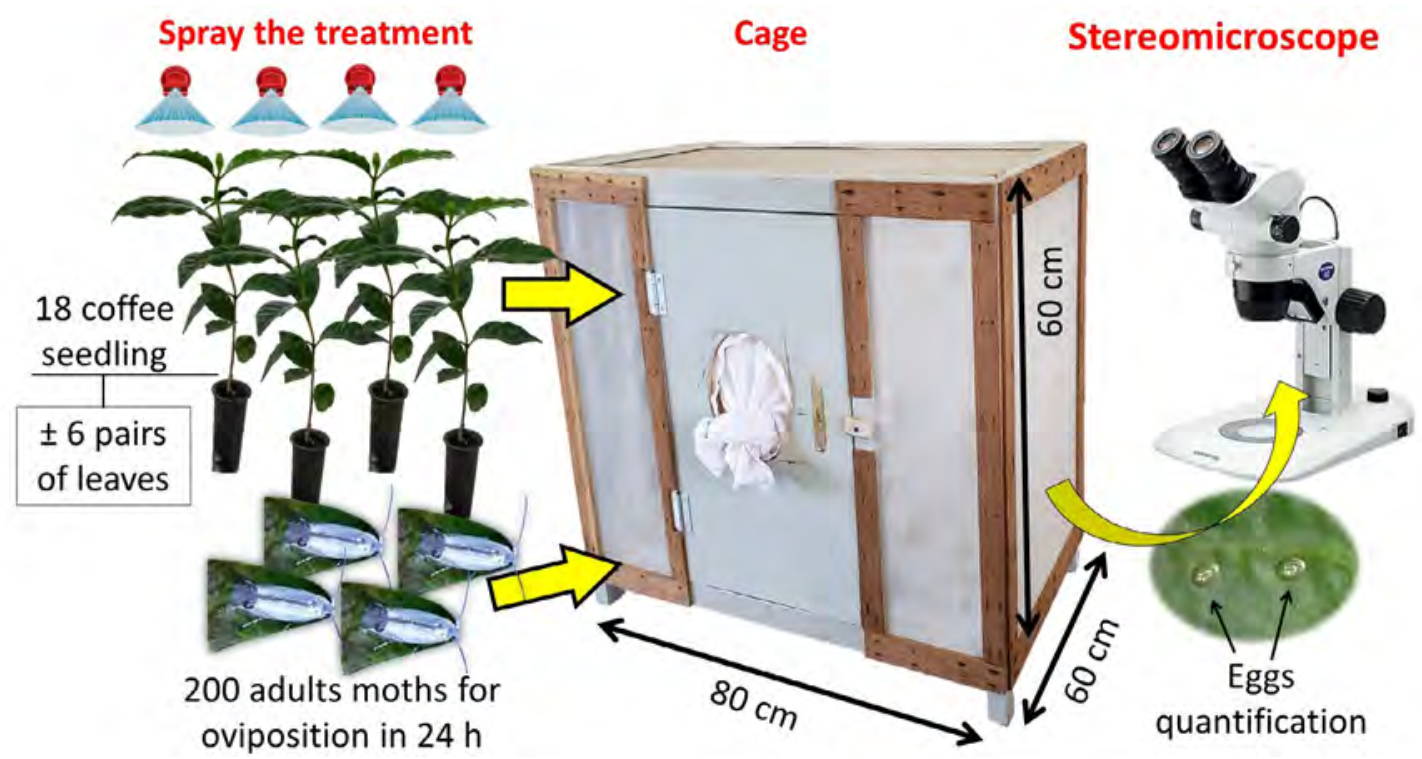

Figure 1: Procedures used during egg counting in no-choice oviposition test.

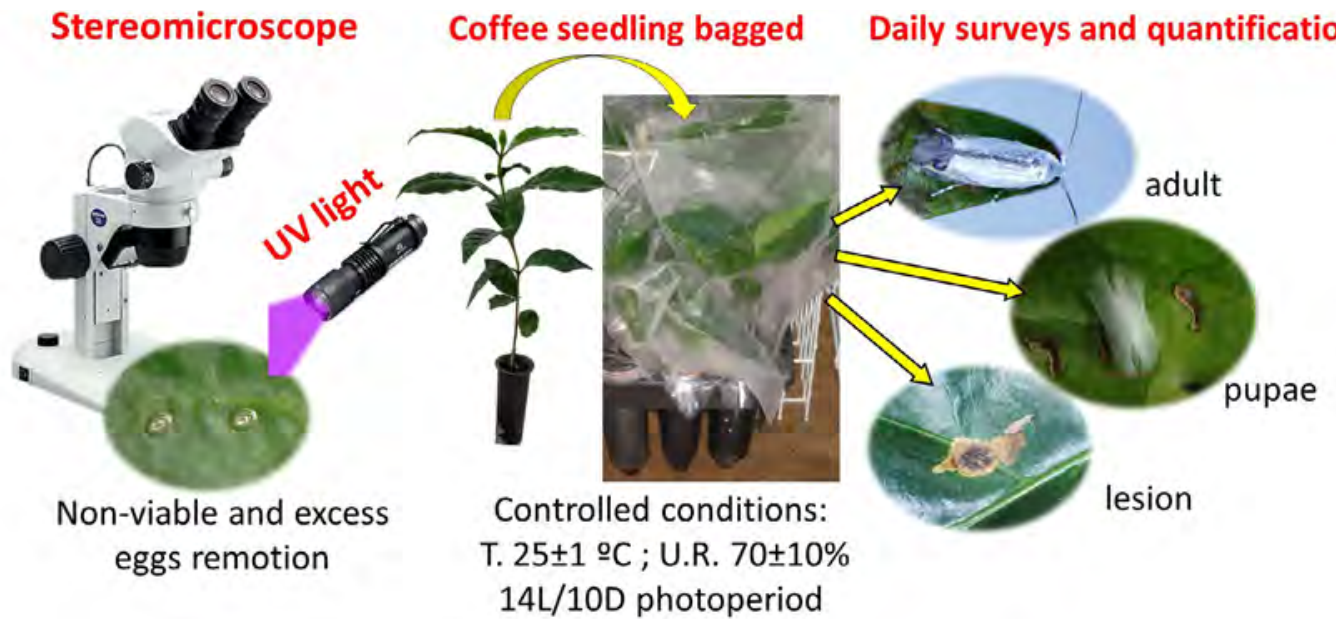

Figure 2: Procedures performed during the quantification of lesions (mines), pupae and adults under controlled conditions in nochoice oviposition test. 


\subsection{Mortality test of first and third instars larvae}

The same procedures described for the eggs viability test were used to obtain coffee sprout with lesions (mines). Lesions with first instar larvae (lesions at the beginning of formation) and for lesions with third instar caterpillars (approximately $0.5 \mathrm{~cm}$ in diameter) were used. 12 hours after spraying, the sprouts were isolated in polyethylene bags, as previously described. Each replicate consisted of five lesions containing larvae. Five replications per treatments were used.

In the evaluations, the sprouts were inspected, recording the number of lesions that remained the same size, those that progressed to a larger size, and the number of pupae and adults that emerged. The lesion progression was observed through their increase in size, measured with a pachymeter, also, with the presence of a brownish edge around the lesion, indicating recent tissue consumption (Figure 3). The larval and accumulative mortality was recorded.

\subsection{Experimental design and statistical analysis}

The experiments were conducted in a randomized block design. Larval and cumulative (larval + pupal) mortality was analyzed. The data were subjected to homoscedasticity and normality analysis to verify the assumptions of parametric analysis. Given the assumptions, analysis of variance was performed and the means compared using the Scott-Knott test at $5 \%$ significance. When the assumptions were not met, the Kruskal-Wallis non-parametric test was performed, followed by Dunn at $5 \%$ significance. The analyzes were performed using the SASM-Agri softwares (Canteri et al., 2001) and BioEstat 5.0 (Ayres, 2007). Mortality correction using the Schneider-Orelli formula was not necessary due to the absence of mortality in control treatments.

\section{RESULTS}

A broad oviposition reduction was observed in the treatments sprayed with propolis, PEPG, neem, and kaolin + neem oil (1.1; 2.7; 3.6 and 2.7 eggs plant ${ }^{-1}$, respectively) when compared to witness sprouts, sprayed with water and no treatment (38.0 and 35.2 eggs plant $^{-1}$, respectively) (Table 2), resulting in reductions of at least $89 \%$. In the sprouts treated with kaolin and lime sulfur, an intermediate number of eggs (12.9 eggs plant $\left.{ }^{-1}\right)$ were registered (reduction of about $60 \%$ ).

The adults released in the cages with coffee sprouts, treated with ethanolic propolis extract, were mostly located on the walls of the cages with little to no movement, which suggests a repellent effect. In the cages with sprouts that received other treatments, movement and flight of the moths were verified close to the coffee leaves. When resting, they remained hidden in the leaves' abaxial surface.

Treatments with neem oil alone or associated with kaolin, caused $98.6 \%$ and $79.0 \%$ larvae mortality, respectively, which indicates a residual effect of neem, from the applications carried out before the oviposition of the $L$. coffeella (Table 2). This mortality was higher than observed in other treatments, especially treatments with propolis, water and with no treatment. Accumulated mortality (egg unto adult), was higher for neem oil and kaolin + neem oil treatments. Intermediate accumulated mortality was observed for PEPG treatment.

\subsection{Viability of eggs after spraying}

The treatments with neem oil, lime sulfur, kaolin + oil and neem reduced the viability of the eggs by $46.4 \%, 37.6 \%$ and $30.4 \%$, respectively. In other treatments, no reduction in viability was observed (Table 3 ).



Figure 3: Coffee sprout in perforated polyethylene bags (A), coffee leaf with lesion (B), lesion detail (C), lesion that progressed, with brownish border, indicating freshly consumed tissue (D). Yellow lines indicate scale. 
Spraying with neem oil alone or associated with kaolin did not allow the emergence of adults $(100 \%$ of accumulated mortality). Lime sulfur, on the other hand, caused $60 \%$ of accumulated mortality. The other treatments, although preventing the development of eggs, caused mortalities lower than $18 \%$ (Table 3 ).

\subsection{Mortality of first and third instar larvae}

Spraying neem oil on lesions containing $L$. coffeella caterpillars of the first or third instars, resulted in $98.4 \%$ and
$81.6 \%$ mortality, respectively. The treatment with kaolin and neem oil, resulted in a reduced mortality ( $48.8 \%$ for the first and $20 \%$ for the third instar). On the other hand, this combination had a sub-lethal effect on the cycle of the $L$. coffeella and prevented the emergence of $95.2 \%$ to $100 \%$ of adults, similar to the isolated application of neem oil (Table 4). With the exception of ethanolic propolis extract treatment and the witnesses (untreated sprouts), which did not cause mortality, all other treatments resulted in the death of $L$. coffeella, although, less than $20 \%$, even for the accumulated larvae to adults (Table 4).

Table 2: Number of eggs per plant, larval and accumulated mortality (mean \pm SE) of $L$. coffeella, in coffee sprouts treated before oviposition.

\begin{tabular}{|c|c|c|c|c|c|c|c|c|c|}
\hline \multirow{3}{*}{$\begin{array}{c}\text { Treatments } \\
\text { Ethanolic extract of propolis }\end{array}$} & \multirow{2}{*}{\multicolumn{3}{|c|}{ Number of eggs plant ${ }^{-1}$}} & \multicolumn{6}{|c|}{ Mortality (\%) } \\
\hline & & & & \multicolumn{3}{|c|}{ Larvae } & \multicolumn{3}{|c|}{ Egg-adult (accumulated) } \\
\hline & 1.1 & \pm 0.6 & $\mathrm{~d}^{1}$ & 0.0 & \pm 0.0 & d & 0.0 & $\pm 0,0$ & $\mathrm{~b}$ \\
\hline Pyroligneous acid + pepper + garlic & 2.7 & \pm 0.9 & $\mathrm{~cd}$ & 14.4 & \pm 4.8 & bcd & 32.0 & \pm 13.6 & $\mathrm{ab}$ \\
\hline Silicate clay & 21.9 & \pm 3.5 & $\mathrm{ab}$ & 2.2 & \pm 1.3 & $\mathrm{~d}$ & 2.2 & \pm 1.3 & b \\
\hline Kaolin & 12.9 & \pm 3.0 & bc & 7.6 & \pm 5.4 & $\mathrm{~d}$ & 7.6 & \pm 5.4 & b \\
\hline Neem seed oil & 3.6 & \pm 1.1 & $\mathrm{~cd}$ & 98.6 & \pm 1.4 & a & 98.6 & \pm 1.4 & a \\
\hline Lime sulfur & 12.9 & \pm 3.1 & bc & 9.6 & \pm 4.1 & d & 9.6 & \pm 4.1 & b \\
\hline Kaolin + Neem seed oil & 2.7 & \pm 0.9 & $\mathrm{~cd}$ & 79.0 & \pm 12.2 & bc & 100.0 & \pm 0.0 & $\mathrm{a}$ \\
\hline Control (Distilled water) & 38.0 & \pm 2.5 & a & 0.0 & \pm 0.0 & d & 2.2 & $\pm 1,3$ & b \\
\hline Control (No treatment) & 35.2 & \pm 5.8 & $\mathrm{ab}$ & 0.0 & \pm 0.0 & d & 0.0 & \pm 0.0 & $\mathrm{~b}$ \\
\hline p-valor & & $<0.01$ & & & $<0.01$ & & & $<0.01$ & \\
\hline
\end{tabular}

${ }^{1}$ Means followed by the same letter, in the column, do not differ by the Kruskal-Wallis test followed by Dunn at $5 \%$ significance.

Table 3: Viability of eggs and accumulated mortality (from egg to adult) (mean \pm SE) of $L$. coffeella, in coffee sprouts treated after oviposition.

\begin{tabular}{|c|c|c|c|c|c|c|}
\hline \multirow{2}{*}{$\begin{array}{l}\text { Treatments } \\
\text { anolic extract of propolis }\end{array}$} & \multicolumn{3}{|c|}{ Viability of eggs } & \multicolumn{3}{|c|}{ Egg-adult mortality (Accumulated) } \\
\hline & 0.0 & \pm 0.0 & $\mathrm{C}^{1}$ & 2.4 & \pm 1.6 & $\mathrm{e}$ \\
\hline Pyroligneous acid + pepper + garlic & 0.8 & \pm 0.8 & $\mathrm{C}$ & 0.8 & \pm 0.8 & $\mathrm{e}$ \\
\hline Silicate clay & 0.0 & \pm 0.0 & c & 17.6 & \pm 3.2 & $\mathrm{C}$ \\
\hline Kaolin & 0.0 & \pm 0.0 & c & 8.0 & \pm 2.1 & $\mathrm{~d}$ \\
\hline Neem seed oil & 46.4 & \pm 4.8 & a & 100.0 & \pm 0.0 & $\mathrm{a}$ \\
\hline Lime sulfur & 37.6 & \pm 3.7 & $\mathrm{~b}$ & 60.0 & \pm 3.3 & $\mathrm{~b}$ \\
\hline Kaolin + Neem seed oil & 30.4 & \pm 4.1 & $\mathrm{~b}$ & 100.0 & \pm 0.0 & $\mathrm{a}$ \\
\hline Control (Distilled water) & 0.0 & \pm 0.0 & c & 0.0 & \pm 0.0 & $\mathrm{e}$ \\
\hline Control (No treatment) & 0.0 & \pm 0.0 & $\mathrm{C}$ & 0.0 & \pm 0.0 & $\mathrm{e}$ \\
\hline C.V. (\%) & & 6.26 & & & 6.23 & \\
\hline p-valor & & $<0.01$ & & & $<0.01$ & \\
\hline
\end{tabular}

${ }^{1}$ Means followed by the same letter, in the column, do not differ by the Scott-Knott at $5 \%$ significance. 
Table 4: Mortality of first and third instar larvae and accumulated mortality of $L$. coffeella from larvae to adult (mean \pm SE) in coffee sprouts treated after lesion formation.

\begin{tabular}{|c|c|c|c|c|c|c|c|c|c|c|c|c|}
\hline \multirow[b]{3}{*}{ Ethanolic extract of propolis } & \multicolumn{12}{|c|}{ Mortality (\%) } \\
\hline & \multicolumn{3}{|c|}{ 1st instar caterpillars } & \multicolumn{3}{|c|}{$\begin{array}{l}\text { Larvae to adult } \\
\text { (accumulated) }\end{array}$} & \multicolumn{3}{|c|}{ 3rd instar caterpillar } & \multicolumn{3}{|c|}{$\begin{array}{l}\text { Larvae to adult } \\
\text { (accumulated) }\end{array}$} \\
\hline & 6.4 & \pm 1.6 & $\mathrm{C}^{1}$ & 7.2 & \pm 2.3 & $\mathrm{C}$ & 0.0 & \pm 0.0 & c & 0.0 & \pm 0.0 & C \\
\hline $\begin{array}{c}\text { Pyroligneous acid + pepper }+ \\
\text { garlic }\end{array}$ & 4.0 & \pm 1.6 & $\mathrm{C}$ & 16.8 & \pm 2.9 & $\mathrm{~b}$ & 1.6 & \pm 0.9 & c & 1.6 & \pm 0.9 & C \\
\hline Silicate clay & 8.8 & \pm 3.5 & $\mathrm{C}$ & 10.4 & \pm 4.6 & $\mathrm{C}$ & 2.4 & \pm 0.9 & c & 2.4 & \pm 0.9 & C \\
\hline Kaolin & 8.0 & \pm 1.7 & $\mathrm{C}$ & 8.0 & \pm 2.5 & $\mathrm{C}$ & 7.2 & \pm 1.4 & c & 7.2 & \pm 1.4 & C \\
\hline Neem seed oil & 98.4 & \pm 0.9 & $\mathrm{a}$ & 98.4 & \pm 0.9 & $\mathrm{a}$ & 81.6 & \pm 2.9 & $\mathrm{a}$ & 98.5 & \pm 1.0 & $\mathrm{a}$ \\
\hline Lime sulfur & 5.6 & \pm 2.9 & $\mathrm{C}$ & 10.4 & \pm 2.7 & $\mathrm{C}$ & 11.2 & \pm 4.6 & $\mathrm{~b}$ & 11.2 & \pm 4.6 & $\mathrm{~b}$ \\
\hline Kaolin + Neem seed oil & 48.8 & \pm 3.8 & $\mathrm{~b}$ & 100.0 & \pm 0.0 & $\mathrm{a}$ & 20.0 & \pm 8.2 & $\mathrm{~b}$ & 95.2 & \pm 1.4 & $\mathrm{a}$ \\
\hline Control (Distilled water) & 0.0 & \pm 0.0 & $\mathrm{~d}$ & 0.0 & \pm 0.0 & $\mathrm{~d}$ & 0.0 & \pm 0.0 & $\mathrm{C}$ & 0.0 & \pm 0.0 & C \\
\hline Control (No treatment) & 0.0 & \pm 0.0 & $\mathrm{~d}$ & 0.0 & \pm 0.0 & $\mathrm{~d}$ & 0.0 & \pm 0.0 & $\mathrm{C}$ & 0.0 & \pm 0.0 & C \\
\hline C.V. (\%) & \multicolumn{3}{|c|}{5.90} & \multicolumn{3}{|c|}{7.00} & \multicolumn{3}{|c|}{8.80} & \multicolumn{3}{|c|}{5.30} \\
\hline p-valor & \multicolumn{3}{|c|}{$<0.01$} & \multicolumn{3}{|c|}{$<0.01$} & \multicolumn{3}{|c|}{$<0.01$} & \multicolumn{3}{|c|}{$<0.01$} \\
\hline
\end{tabular}

${ }^{1}$ Means followed by the same letter, in the column, do not differ by the Scott-Knott at $5 \%$ significance.

\section{DISCUSSION}

The reduction of CLM oviposition with propolis extract, may be caused by its composition (alcohols, phenols and esters) (Bankova; de Castro; Marcucci, 2000) and also due to the mechanical effect, because of the adhesiveness of the wax and resin present in the propolis (Cirasino; Pisati; Fasani, 1987). These traits represent a repellent or deterrent effect on the oviposition. In the cages in which plants were treated with propolis, insects in general, demonstrated reduced movements and were located in the cage walls.

The "anesthetic" effect on insects provided by the ethanolic propolis extract was also previously observed on Tenebrio molitor L. (Coleoptera: Tenebrionidae) larvae and adults (Garedew et al., 2002). Also, for the green aphid, Myzus persicae Sulzer (Hemiptera: Aphididae), repellency from the propolis extract was verified (Rocha; Santos; GolçalvesGervário, 2017). For the Varroa destructor Anderson \& Trueman (Acari: Varroidae), the same previous effect was observed (Damiani et al., 2010). This agrees with the nature of propolis' role in the bee nests where it may repel insects that could eventually invade the colony (Boongird, 2010) as seen previously against the predatory ants of the genus Oecophylla (Duangphakdee et al., 2009).

The PEPG spraying reduced the oviposition of the $L$. coffeella. Repelent effects of pyroligneous acid against the oviposition of the whitefly, Bemisia tabaci Gennadius biotype B (Hemiptera: Aleyrodidae), was also found on melon plants (Azevedo et al., 2005). Repellency and insecticide effects on aphids, scale insects, thrips, etc., have also been reported (Botti et al., 2015; Gomes et al., 2017; Santos et al., 1988). Garlic also has a wide action spectrum for repellency and negative effects against insects and mites (Attia et al., 2012; Fening et al., 2013; Hata et al., 2020; Mobki et al., 2014).

The neem oil treatment affected the oviposition behavior of the L. coffeella, possibly due to the ability of the lepidopterans to identify harmful allelochemicals, such as azadirachtin, through tarsal chemoreceptors (Blaney; Simmonds, 1990), which are involved in the selection of the oviposition site. Previously, neem extracts also reduced the oviposition of other species of lepidoptera such as Spodoptera littoralis Boisduval (Lepidoptera: Noctuidae) (Martinez; Van Emden, 2001); Eiras vitella Fab. (Lepidoptera: Noctuidae) (Gajmer et al., 2002) and Plutella xylostella L. (Chandramohan; Nanja, 1992; Verkerk; Wright, 1993).

Reductions of more than $50 \%$ for CLM oviposition in tests with or no choice using treated neem oil sprouts were previously reported (Martinez; Meneguim 2003). However, in another study, no differences were found Venzon et al. (2005). This inconsistency in results is probably due to the differing concentrations of active components, such as the azadirachtin.

A complex of stimuli and responses are involved in the choice of the insect towards the host plant for oviposition, due to its sensory system, which has receptors capable of recognizing the metabolites produced by the plants (Städler; Reifenrath, 2009). This recognition may increase or even reduce oviposition Fanela et al. (2020).

The mixture kaolin + neem oil also reduced the CLM oviposition, due to, neem presence, as kaolin results were similar to control. These findings did not correspond to results 
obtained previously by using kaolin for Zabrotes subfasciatus Boh. (Coleoptera: Bruchidae), when kaolin reduced oviposition and modified female behavior (eggs were laid on the walls of the flasks and not on the seeds) (Mikami et al., 2010).

Although every egg generated larvae in the no choice experiment, plants treated with neem oil resulted in larvae mortality, thus preventing the formation of adults. Previously, emergence of CLM adults was also hindered due to mortality of larvae and pupae (Fanela et al. 2020). Plant chemicals in neem oil, such as azadirachtin, are reported to have a systemic and translaminar action on plants (Coelho Junior; Deschamps, 2014), which may have fostered the low CLM emergence of L. coffeella adults in treatments containing neem oil, applied before oviposition. Previously, the translaminar effect of neem oil on bean leaves caused a large mortality of larvae, diminishing pupae formation and, at higher concentrations, prevented the emergence of Liriomyza huidobrensis (Blanchard) adults (Weintraub; Horowitz, 1997).

The ovicidal action of the lime sulfur may be a result of the hydrogen sulphide gas $\left(\mathrm{H}_{2} \mathrm{~S}\right)$, which is the element that causes a toxic effect on insects, mites and fungi (Abbott et al., 1945) and also could be the colloidal sulfur formed when applied on the plant's surface. Similar effects were reported by using this treatment to manage the red mite Oligonychus ilicis McGregor (Acari: Tetranychidae) on coffee (Tuelher et al., 2014); and the grapevine scale Parthenolecanium persicae Fabricius (Hemiptera: Coccidae) (Afonso et al., 2007).

Spraying neem oil and the mixture kaolin + neem oil at $1 \%$ on the eggs, reduced eggs viability by $46 \%$ and $37 \%$, respectively. This ovicidal action of neem oil was previously observed, at $0.12 \%$ and $0.25 \%$ (viability reduction of 48 and $52 \%$ ); and at $1.25 \%$ and $2.5 \%$ (71.5\%) (Martinez; Meneguim 2003). Besides ovicidal action, the residual effect is long enough to prevent the first ecdysis of hatched larvae (Venzon et al., 2005).

For the survival test on 3rd instar caterpillar, just neem oil and kaolin + neem oil caused mortality equal or above $20 \%$ and, as consequence, reduction of more than $95 \%$ of emerging adults (Table 4). Similar results were also previously reported when testing neem oil in the concentrations of 0.025 to 0.1 g azadirachtin $\mathrm{L}^{-1}$ (Venzon et al., 2005). These authors highlighted the penetration of the active components into the leaves, paralyzing CLM development and preventing the emergence of adults.

The use of neem oil in an integrated pest management program should be carried out carefully. Studies show that depending on the natural enemy, the neem oil exposition caused a significant mortality of Chrysoperla externa Hagen (Souza et al., 2020), but for Proprioseiopsis neotropicus Ehara (Acari: Phytoseiidae) and Phytoseiulus macropilis Banks (Acari: Phytoseiidae) the neem oil was selective (Veronez; Sato; Nicastro, 2012; Silva et al., 2013).

\section{CONCLUSIONS}

The treatments neem oil, kaolin + neem oil, ethanolic propolis extract and pyroligneous acid + pepper + garlic reduced the oviposition of $L$. coffeella in coffee sprouts, under controlled conditions in no choice tests.

Ovicidal activity was obtained through spraying neem oil on eggs, which also caused total mortality of hatched larvae.

Neem oil, sprayed on mines, caused high mortality of larvae in the first and third instar of the L. coffeella. The mixture of kaolin + neem oil prevented the emergence of adults.

The addition of kaolin to neem oil delays the toxic action of neem when applied to eggs or larvae inside the mines.

\section{AUTHORS CONTRIBUTIONS}

HGA wrote the manuscript and performed the experiments, ATH co-worked the manuscript and conducted statistical analyzes, AMM supervised the experiments, MUV reviewed and approved the final version of the work, BAG assisted in writing the manuscript, FTH co-wrote and translated it into English, AOM Jr supervised the research, planned experiments and final approval of the work.

\section{REFERENCES}

ABBOTT, C. E. The toxic gases of lime-sulfur. Journal of Economic Entomology, 38:618-620, 1945.

AFONSO, A. P. S et al. Avaliação da calda sulfocálcica e do óleo mineral no controle da cochonilha-parda Parthenolecanium persicae (Hemiptera: Coccidae) na cultura da videira. Arquivos Instituto Biológico, 74(2):167-169, 2007.

ALVES, M. et al. Ação de diferentes preparações de extrato pirolenhoso sobre Brevipalpus phoenicis (GEIJSKES). Revista Brasileira de Fruticultura, 29(2):382-385, 2007.

ATTIA, S. et al. Acaricidal activity of 31 essential oils extracted from plants collected in Tunisia. Journal of Essential Oil Research, 24(3):279-288, 2012.

AYRES, M. et al. BioEstat 5.0: Aplicações estatísticas nas áreas das ciências biológicas e médicas. $5^{\text {a }}$ ed. Belém: Sociedade Civil Mamirauá, Conselho Nacional de Desenvolvimento Científico e Tecnológico, Brasília, 2007. 380p.

AZEVEDO, F. R. DE. et al. Eficiência de produtos naturais para o controle de Bemisia tabaci biotipo B (Hemiptera: Aleyrodidae) em meloeiro. Arquivos do Instituto Biológico, 72(1):73-79, 2005. 
BANKOVA, V. S.; DE CASTRO, S. L.; MARCUCCI, M. C. Propolis: Recent advances in chemistry and plant origin. Apidologie, 31:3-15, 2000.

BLANEY, W. M.; SIMMONDS, M. S. J. A behavioural and electrophysiological study of the role of tarsal chemoreceptors in feeding by adults of Spodoptera littoralis, Heliothis virescens and Helicoverpa armigera. Journal of Insect Physiology, 36:743-756, 1990.

BENELLI, G. et al. Neem (Azadirachta indica): Towards the ideal insecticide?. Natural Product Research, 31(4):369386, 2016.

BOONGIRD, S. Honey and non-honey foods from bees in Thailand. In: DURST, P. B et al. Forest insects as food: Humans bite back. Food and agriculture organization of the united nations regional office for Asia and the Pacific, p.165-172, 2010.

BOTTI, J. M. C. Controle alternativo do Brevicoryne brassicae (Hemiptera: Aphididae) com extratos de diferentes espécies de plantas. Revista Brasileira de Ciências Agrárias, 10(2):178-183, 2015.

CANTERI, M. G. et al. SASM - Agri: Sistema para análise e separação de médias em experimentos agrícolas pelos métodos Scott-Knott, Tukey e Duncan. Revista Brasileira de Agrocomputação, 1(2):18-24, 2001.

\section{CONSELHO DOS EXPORTADORES DE CAFÉ DO} BRASIL - CECAFÉ. Exportações brasileiras de café. 2020. Available in: $<$ https://www.conab.gov.br/info-agro/ safras/cafe $>$. Access in: 25, November, 2021.

CHANDRAMOHAN, N.; NAMJA, N. Effect of plant product spray on the ovipositional behaviour of diamond back moth, Plutella xylostella (L.). Neem Newsletter, 9(1):8-9, 1992.

CHAUDHARY, S. et al. Progress on Azadirachta indica based biopesticides in replacing synthetic toxic pesticides. Frontiers In Plant Science, 8:610, 2017.

CIRASINO, L.; PISATI, A.; FASANI, F. Contact dermatitis from propolis. Contact Dermatitis, 16:110-111, 1987.

COELHO JUNIOR, A.; DESCHAMPS, F. C. Ação sistêmica e translaminar do óleo de nim visando ao controle de Tuta absoluta (Meyrick)(Lep.: Gelechiidae) em tomateiro. Arquivos do Instituto Biológico, 81(2):140-144, 2014.

\section{COMPANHIA NACIONAL DE ABASTECIMENTO -} CONAB. Acompanhamento da safra brasileira de café - Safra 2020 - Primeiro Levantamento. CONAB, Brasília - DF. 2020. Available in: <https://www.conab.gov.br/infoagro/safras/cafe>. Access in: May, 17, 2021.
DAMIANI, N. et al. Evaluation of the toxicity of a propolis extract on Varroa destructor (Acari: Varroidae) and Apis mellifera (Hymenoptera: Apidae). Journal of Apicultural Research, 49(3):257-264, 2010.

DAVID-RUEDA, G. et al. Diagnóstico de Leucoptera coffeella (Lepidoptera: Lyonitiidae) y sus parasitoides en el departamento de Antioquia, Colombia. Revista Colombiana de Entomologia, 42(1):4-11, 2016.

DUANGPHAKDEE, O. et al. Ant repellent resins of honeybees and stingless bees. Insectes Sociaux, 56:333, 2009.

EROGLU, N.; EMEKCI, M.; ATHANASSIOU, C. G. Applications of natural zeolites on agriculture and food production. Journal of the Science of Food and Agriculture, 97(11):3487-3499, 2017.

FANELA, T. L. M. et al. Assessing potential plants extracts to reduce Leucoptera coffeella (lepidoptera: Lyonetiidae) attack in coffee. Coffee Science, 15:e151653, 2020.

FENING, K. O. et al. Sustainable management of two key pests of cabbage, Brassica oleracea var. capitata L.(Brassicaceae), using homemade extracts from garlic and hot pepper. Organic agriculture, 3:163173, 2013.

GAJMER, T. R. et al. Effect of methanolic extracts of neem (Azadiractha indica A. Juss) and bakain (Melia azedarach L.) seeds on oviposition and egg hatching of Eiras vitella (Fab.) (Lep., Noctuidae). Journal of Applied Entomology, 126(5):238-243, 2002.

GAREDEW, A. et al. Microcalorimetric toxicity investigation of propolis on Tenebrio molitor L. (Coleoptera: Tenebrionidae). Thermochimica Acta, 394(1-2):239-245, 2002.

GOMES, F. H. T. et al. Atividade inseticida de extratos vegetais sobre o pulgão-preto do feijoeiro. Revista de Ciências Agroambientais, 15(1):43-52, 2017.

GONÇALVES, S. G. et al. Oviposição do curuquerê e alimentação de suas lagartas neonatas em algodoeiros tratados com caulim. Pesquisa Agropecuária Brasileira, 50(7):526-533, 2015.

HATA, F. T. et al. Plant acceptance for oviposition of Tetranychus urticae on strawberry leaves is influenced by aromatic plants in laboratory and greenhouse intercropping experiments. Agronomy, 10(2):193, 2020.

ISMAN, M. B. Botanical insecticides in the twenty-first century - fulfilling their promise?. Annual Review of Entomology, 65:233-249, 2020. 
SHAH, M. A.; KHAN, A. A. Use of diatomaceous earth for the management of stored-product pests. International Journal of Pest Management, 60(2):100-113, 2014.

LEITE, S. A. et al. Profile of coffee crops and management of the Neotropical coffee leaf miner, Leucoptera coffeella. Sustainability, 12(19):8011, 2020.

LIŠKA, A. et al. Efficacy of nine croatian inert dusts against rice weevil Sitophilus oryzae L.(Coleoptera: Curculionidae) on wheat. Emirates Journal of Food and Agriculture, 29(7):485-494, 2017.

MARTINEZ, S. S.; MENEGUIM, A. M. Redução da oviposição e da sobrevivência de ovos de Leucoptera coffeella causadas pelo óleo emocionável de Nim. Manejo integrado de Plagas y Agroecologia, 67:58-62, 2003.

MARTINEZ, S. S.; VAN EMDEN, H. F. Growth disruption, abnormalities and mortality of Spodoptera littoralis (Boisduval) (Lepidoptera: Noctuidae) caused by Azadirachtin. Neotropical Entomology, 30(1):113-124, 2001

MEEMKEN, E. M. Do smallholder farmers benefit from sustainability standards? A systematic review and metaanalysis. Global Food Security, 26:100373, 2020.

MMOJIEJE, J.; HORNUNG, A. The potential application of pyroligneous acid in the UK agricultural industry. Journal of Crop Improvement, 29(2):228-246, 2015.

MIKAMI, A. Y. et al. Controle do caruncho-do-feijão Zabrotes subfasciatus com caulim. Ciência Rural, 40(7):1497-1501, 2010.

MOBKI, M. et al. Toxicity and repellency of garlic (Allium sativum L.) extract grown in Iran against Tribolium castaneum (Herbst) larvae and adults. Archives of Phytopathology and Plant Protection, 47(1):59-68, 2014.

PENTEADO, S. R. Controle alternativo de pragas e doenças com as caldas bordalesa, sulfocálcica e Viçosa. Campinas: Buena Mendes Gráfica e Editora, 2000. 95p.

ROCHA, A. M. S.; SANTOS, A. J. S.; GOLÇALVESGERVÁRIO, R. C. R. Bioatividade de extratos de própolis sobre o pulgão Myzuz persicae Sulzer
(Hemiptera: Aphididae) em couve manteiga. Revista de Ciências Agroveterinárias, 16(3):332-337, 2017.

SANTOS, J. H. R. dos. et al. Controle alternativo de pragas e doenças. Fortaleza: UFC, 1988. 216p.

SILVA, A. C. B. et al. Lethal and sublethal effects of neem oil to the predatory mite Proprioseiopsis neotropicus (Acari: Phytoseiidae). Revista Colombiana de Entomología, 39: 221-225, 2013.

STÄDLER, E.; REIFENRATH, E. K. Glucosinolates on the leaf surface perceived by insect herbivores: Review of ambiguous results and new investigations. Phytochemistry Reviews, 8:207-225, 2009.

SOUZA, J. R. et al. Susceptibility of Chrysoperla externa (Hagen, 1861) (Neuroptera: Crysopidae) to insecticides used in coffee crops. Ecotoxicology, 29:1306-1314, 2020.

TAIZ, L. et al. Fisiologia e desenvolvimento vegetal. $6^{\text {a }}$ Ed. Porto Alegre- RS: Artmed, 2017. 888p.

TUELHER, E.S. et al. Toxicity of organic-coffee-approved products to the southern red mite Oligonychus ilicis and to its predator Iphiseiodes zuluagai. Crop Protection, 55:28-34, 2014.

WEINTRAUB, P. G.; HOROWITZ, A. R. Systemic effects of a neem insecticide on Liriomyza huidobrensis Larvae. Phytoparasitica, 25(4):283-289, 1997.

WILLER, H. et al. The world of organic agriculture statistics and emerging trends 2021. Research institute of organic agriculture FiBL, IFOAM - Organic International. Bonn - Germany, 2021.340p.

VENZON, M. et al. The potential of NeemAzal for the control of coffee leaf pests. Crop Protection, 24(3):213219, 2005.

VERKERK, R. H. J.; WRIGHT, D. J. Biological activity of neem seed kernel extracts and synthetic azadirachtin against larvae of Plutella xylostella L. Pesticide Science, 37(1):83-91, 1993.

VERONEZ, B.; SATO, M. E.; NICASTRO, R. L. Toxicidade de compostos sintéticos e naturais sobre Tetranychus urticae e o predador Phytoseiulus macropilis. Pesquisa Agropecuária Brasileira, 47(4):511-518, 2012. 